Volume and Issues Obtainable at Center for Sustainability Research and Consultancy

Journal of Business and Social Review in Emerging Economies

ISSN: 2519-089X (E): 2519-0326

Volume 4: Issue 1June 2018

Journal homepage: www.publishing.globalcsrc.org/jbsee

\title{
Mind the Gap: What are the Barriers to Pro-Environmental Behavior among Students?
}

\author{
${ }^{1}$ Anissa Lestari Kadiyono, ${ }^{2}$ Diana Harding, ${ }^{3}$ Hanny Hafiar, ${ }^{4}$ Hery Wibowo \\ ${ }^{1}$ Fakultas Psikologi - Universitas Padjadjaran, Indonesia. anissa.lestari@unpad.ac.id \\ ${ }^{2}$ Fakultas Psikologi - Universitas Padjadjaran, Indonesia. diana.harding@unpad.ac.id \\ ${ }^{3}$ Fakultas Ilmu Komunikasi - Universitas Padjadjaran, Indonesia. hanny.hafiar@unpad.ac.id \\ ${ }^{4}$ Fakultas Ilmu Sosial dan Ilmu Politik - Universitas Padjadjaran, Indonesia. hery.wibowo@unpad.ac.id
}

\section{ARTICLE DETAILS}

\section{History}

Revised format: May 2018

Available Online: June 2018

\section{Keywords}

Environmental Education, Pro-

Environmental Behavior,

Education

JEL Classification:

K32, K39, I12, $I 19$

\begin{abstract}
Education is one of the potential efforts in overcoming the current and future environmental crisis. Cultivation of awareness of the preservation of natural resources and environment within the school environment can be done through teaching and learning process that contains environmental education, green school environment, and supported by school facilities. Numerous theoretical frameworks have been developed to explain the gap between the possession of environmental knowledge and environmental awareness, and displaying pro-environmental behavior. This research describes what factors will influence pro-environmental behavior at students. Using Quantitative method and Convenience Sampling at students in Junior High School at Bandung-West Java Indonesia. Internal and External factors were analyzed to discover positive and negative aspect that influenced pro-environmental behavior such as demographic factors, external factors (e.g. school, economic, social and cultural) and internal factors (e.g. motivation, pro-environmental knowledge, awareness, values, attitudes, responsibilities and priorities). Specific recommendations for school are provided, and implication for educators are discussed. Finally suggestion for further research on pro-environmental behavior at students are provided. Environmental education at school are important as the basis of formation at green ethics across generations.
\end{abstract}

(C) 2018 The authors, under a Creative Commons Attribution-

NonCommercial 4.0

Corresponding author's email address: anissa.lestari@unpad.ac.id

Recommended citation: Kadiyono, A.L., Harding, D., Hafiar, H., Wibowo, H. (2018). Mind the Gap: What are the Barriers to Pro-Environmental Behavior among Students? Journal of Business and Social Review in Emerging Economies, 4(1) 1-6

DOI: $10.26710 /$ jbsee.v4i1.351

\section{Introduction}

Global warming is irreversible and can have a terrible impact. General Secretary of United Nation, Ban Ki Moon challenges governments from countries around the world to take concrete action overcome these threats. "Very urgent, global efforts must be done," said Ban Ki-Moon. He hopes policy makers from around the world can respond to these findings at a climate change conference held in Bali in December 2007. Environmental damage has led to extreme weather conditions. Drought occurring in some areas will decrease land productivity and water quality. Sea level rise will trigger wider floods, marinate fresh water, 
and erode coastal areas. Reports from the conference in Bali, it turns out that humans as the most effected by the global warming, consequently humans will also face this problem with increasing population risk, including the emergence of diseases that are related to heat (heat stroke) and death.

Humans as part of the environment, plays an important role. One of the efforts that can be done is through education and shaping environmentally conscious behavior through learning methods in the educational setting, It is expected to be more effective, the role of teachers and school organizations is very important to socialize and implement it. Thus gradually internalized into environmental green ethos characters that become the basic actions of the individual to environmentally conscious. According to Bandura, behavior arises as a result of interaction between the environment and the individual. The more often the stimulus given to humans by the experience gained from the environment, the behavioral changes in the individual will have a positive impact on the desired behavioral change that is the harmony between the environment and the human behavior that lives in it through the learning process (Gagne 1984 in Dahar 1989).

Fomal educational path start from Kindergarten level up to the University level. The concept of formal operational thinking in adolescence begins at the equivalent of junior high school students. Junior high school students are in the adolescent phase, which is a transition period or a transition from late childhood to adulthood. Individual self-development as the actors of change and actors of action on the environment, actually began during the process of identity formation that began in adolescence, or at the time of junior high school.

Early adolescents have a developmental task to develop the intellectual skills and concepts necessary for citizens. Developmental tasks that must also be met are achieving socially responsible behavior as members of the community, as well as obtaining a set of values and ethical systems as a guide in behaving. This also means developing a caring character towards the environment as a responsibility to preserve nature.

The phenomenon that exists, shows the character of adolescents who are less concerned or even do not know the surrounding environment. This is obtained from direct observation and interviews with some community leaders in the surrounding area.

Cognitive dimensions, affective dimensions, and psychomotor dimensions shape environmental concerns that show a predisposition of environmental caring behaviors to be displayed by students. In addition to attitudes, also observed an interest in the environment, values (Values) adopted, as well as behavioral predisposition that refers to the theory of planned behavior consisting of: Behavioral beliefs, defined as beliefs on behavior that will shape the attitude of care for the environment, combined with the normative belief that gives students' norms and control beliefs that will provide perceived behavioral control so as to form behavioral intentions that demonstrate eco-friendly behavior.

Bandung city is the capital of West Java province. The city was in ancient times known as Parijs van Java (Dutch) or "Paris from Java", because it is located in the highlands. Bandung is known as a cool place, this makes Bandung as one of the tourist destination city. While the existence of state universities and many private universities in Bandung make this city known as one of the city students in Indonesia. The city of Bandung is also not spared from climate change and global warming. Bandung as the capital of West Java Province which has the densest population of other provinces in Indonesia should also think about efforts to save the environment in the region. This effort should be implemented early because it prevents it from treating better. Bandung city, divided by geographical area, which has environmental contours and different specific environmental problems. In this study, the city of Bandung is divided into areas of Central Bandung, North Bandung, South Bandung, East Bandung, and West Bandung.

Based on the background that has been presented in the introductory chapter, it can be formulated several things, namely: How about the environmental caring character (Green ethos character) of junior high school students as the next generation consisting of attitude, interests, values, and plan behavior? 


\section{Method}

- Design

This research is a quantitative approach. Quantitative approach is done by doing research on schools in the city of Bandung, the State Junior High School in Central Bandung zone, East Bandung zone, South Bandung zone, North Bandung zone, and West Bandung zone. The method used for this research is descriptive method by using survey technique through questionnaire.

- Sample

Primary data samples that will be used in this study are students of SMP Negeri which has 51 schools in Bandung. Sample determination using sampling technique with Cluster Random Sampling type, where sampling based on certain area so that the expected samples can represent the number of population of junior high school students in Bandung. Cluster is divided into the geographical area of Bandung, with the determination as follows. Respondents in this study amounted to 2150 students from 10 Junior high school in Bandung.

\begin{tabular}{|l|l|l|}
\hline No & Cluster Zone & Total \\
\hline 1 & Central Zone & 2 Junior high school \\
\hline 2 & East Zone & 2 Junior high school \\
\hline 3 & West Zone & 2 Junior high school \\
\hline 4 & South Zone & 2 Junior high school \\
\hline 5 & North Zone & 2 Junior high school \\
\hline
\end{tabular}

- Procedure

Data needed in this research is primary data that is needed especially to answer the purpose of research through descriptive and verifikatif statistical analysis. Primary data will be conducted is to mapping green ethos character of junior high school student. The instrument of collecting data used is questionnaire, that is list of structured questions addressed to respondents in this case junior high school students selected as sample.

- Instrument

Green ethos character is measured through: cognitive dimension, affective dimension, psychomotor dimension. Besides attitude, also measured interest in environment, value (Values), and behavioral predisposition which refers to the theory of Plan Behavior consisting of: Behavioral beliefs, defined as belief in behavior that will shape the attitude of caring about the environment, combined with the normative belief that gives the student's Student Norm and Control Beliefs that will provide Perceived Behavioral Control to form a Behavioral Behavior that demonstrates Eco-Friendly Behavior. The instrument consist of 23 items.

- Statistic

In mapping green ethos character in junior high school students in Bandung, this research will use Multivariate Data Analysis (MDA) method approach through factor and multiple regression analysis. These models are used to process primary data. Data processing using Ms. software Excell and SPSS.

\section{Result}

Table 1. Demographic Data

\begin{tabular}{|l|l|}
\hline Category & Total (Percentage) \\
\hline $\begin{array}{c}\text { Gender } \\
\bullet \quad \text { Male }\end{array}$ & $875(40 \%)$ \\
$\bullet \quad$ Female & $1275(60 \%)$ \\
\hline School & \\
$\bullet \quad$ SMPN 1 & $192(9 \%)$ \\
- SMPN 2 & $95(4 \%)$ \\
$\bullet \quad$ SMPN 5 & $106(5 \%)$ \\
$\bullet$ & $314(15 \%)$ \\
- SMPN 9 & $308(14 \%)$ \\
\hline
\end{tabular}




\begin{tabular}{|c|c|}
\hline $\begin{array}{ll}\text { - } & \text { SMPN } 13 \\
\text { - } & \text { SMPN } 26 \\
\text { - } & \text { SMPN } 34 \\
\text { - } & \text { SMPN } 50\end{array}$ & $\begin{array}{l}289(14 \%) \\
266(12 \%) \\
243(11 \%) \\
337(16 \%)\end{array}$ \\
\hline $\begin{array}{cc}\text { Grade } & \\
\bullet & \text { VII } \\
\bullet & \text { VIII } \\
\bullet & \text { IX }\end{array}$ & $\begin{array}{l}865(40 \%) \\
521(24 \%) \\
764(36 \%)\end{array}$ \\
\hline
\end{tabular}

In accordance to table 1, the respondents of this study were dominated by female respondents of $60 \%$ (1275 respondents), while 40\% (875 respondents) were male. Therefore it can be concluded that the majority respondents of this study are female.

In this research, questionnaire spread to 9 State Junior High School (SMPN) in Bandung, so that based on table 1 can be seen that the respondents in this study by 9\% (192 respondents) came from SMPN 1 Bandung, 4\% (95 respondents) came from SMPN 2 Bandung, 5\% (106) respondents came from SMPN 5 Bandung, 15\% (314 respondents) came from SMPN 9 Bandung, 14\% (308 respondents) came from SMPN 12 Bandung, 14\% (289 respondents) came from SMPN 13 Bandung, 12\% (266 respondents) came from SMPN 26 Bandung, 11\% (243) respondents came from SMPN 34 Bandung, and the rest as much as 16\% (337 respondents) came from SMPN 50 Bandung. That is, the respondents in this study were dominated by students who came from SMPN 50 Bandung.

Based on the table 1, it is also known that the level of respondent grade,as much $40 \%$ (865 respondents) are in grade VII, 24\% (521 respondents) are in grade VIII, and 36\% (764 respondents) are in grade IX. This shows that the majority respondents in this study are at grade VII.

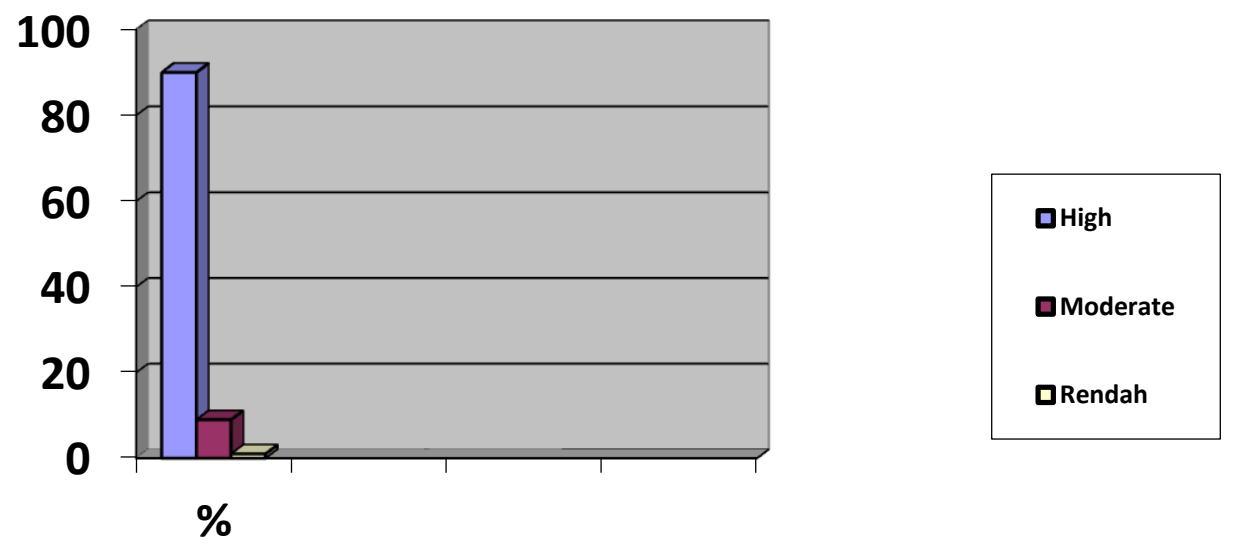

Diagram 1. Green Ethos Character Of Junior High School Student

These results show that $90 \%$ of respondents have high green ethos character. But there are still $9 \%$ who are in the medium category and $1 \%$ are in the low category. The $5^{\text {th }}$ dimension is the lowest dimension, that is value to preserve the environment. This can be enhanced by instilling the character of environmental care to students through the formal path through environmental education.

\section{Discussion}

These results show that majority of respondents have high green ethos character. Green ethos character measure by 8 dimension. First dimension is cognitive dimension, followed by affective dimension, psychomotor dimension. Besides attitude, also measured interest in environment as forth dimension, values as fifth dimension, and behavioral predisposition which refers to the theory of Plan Behavior consisting of: Behavioral beliefs as sixth dimension, defined as belief in behavior that will shape the attitude of caring about the environment, combined with the normative belief that gives the student's 
Student Norm as a seventh dimension and Control Beliefs that will provide Perceived Behavioral Control as an eight dimension.

Based on result from cognitive dimension; parents, teachers, education (schools) have high impact on shaping student on green ethos character. On the other side, internet, media, friend, and own interest have a low impact on shaping green ethos character on junior high school students in Bandung.

To find out the dimensions that become the strongest predictor of the total score of Green Ethos, researchers conducted a regression test. Before performing the regression test, the researcher first convert the data, which previously has an ordinal ordinal scale, into an interval scale using the method of successive interval. After regression analysis, it was found that dimension 6 was a strong predictor of total Green Ethos score. This suggests that Beliefs or behavioral beliefs factor is the internal belief that environmental loving behavior is the main factor that can provide a relationship that also predicts the emergence of environmentally sound behavior. This is in line with the concept of planting the character of environmental love which is a factor of the inner self that underlies the behavior that will be raised by the individual. Belief that belongs to the student will link the behavior with the results that can be obtained from the behavior. Attitudes toward behavior are determined by individual evaluations of behavior-related results and with the strength of the relationships of both (Ajzen, 2005).

Based on the results of different test conducted by using Kruskal Wallis statistic test, which used to test different ordinal data from k-independent sample, it was found that from 9 schools were compared, there were significant differences in dimensions 1 (Cognitive), dimension 3 (Psychomotor), dimension 6 (beliefs), and dimensions 7 (norms). While in other dimensions there is no significant difference. Meanwhile, for the overall results of 9 junior high school in Bandung, there is no significant difference in the value of Green Ethos students. That is, the level of Green Ethos Junior High School students in the city of Bandung are at relatively the same level.

Researchers also conducted analysis by sex. Using the Mann-Whitney statistical test, there was no significant difference in the score of each Green Ethos dimension and the total Green Ethos score when compared by gender. So it can be said that male and female students in junior high school in Bandung have Green Ethos who are in the same level.

\section{References}

Ajzen, I. 1988. Attitudes, Personality, and Behavior. Milton Keynes: Open University Press. Arikunto. 2006. Prosedur Penelitian Suatu Pendekatan Praktik. Jakarta: Rineka Cipta.

Azwar, S. 2007. Sikap Manusia Teori dan Pengukurannya, edisi 2, Yogyakarta: Pustaka Pelajar.

Anderson, At. AL. 2001. A Taxonomy for Learning, Teaching, And Assessing : Revision of Bloom's Taxonomy of Educational Objectives. USA : Addison Wesley Longman.

Black, J. B. and McClintock, R. O. 1995. Constructivist Learning Environment, New Jersey: Englewood Cliff, Educational Technology Publications

Bloom. 1979. Taxonomy of Educational Objectives :The Classification of Educational Goals. London. Longman Group LTD.

BPLH Provinsi Jawa Barat. 2007. Status Lingkungan Hidup tahunan Jawa Barat 2007. Bandung : BPLHD Provinsi Jawa Barat.

Chiras, D. D. 1992.Lessons from Nature:Learning to Live Sustainably on the Earth. Washington D.C.: Island Press

Conger. 1991. Adolescence and Youth, Psychological Development in a Changing World (4th ed.). New Jersey: Prentice Hall.

Departemen Pendidikan Nasional. 2003. Pendekatan Kontekstual. Jakarta: Direktorat Pendidikan Lanjutan Pertama

Dinas Pendidikan Kota Bandung. 2007. Peraturan walikota Bandung Nomor 031 tahun 2007 : Tentang 
Kurikulum Muatan Lokal Pendidikan Lingkungan Hidup Kota Bandung. Bandung : Dinas Pendidikan Kota Bandung.

Eagly, A. H. \& Chaiken, S. 1993. The Psychology of Attitudes. Fort Worth, TX: Harcourt Brace Jovanovitch.

Effendi, Sofian. 1989. Metode Penelitian Survei. Jakarta: LP3ES.

Fishbein, M. \& Ajzen, I. 1975.Belief, Attitude, Intention, and Behavior: An Introduction to Theory and Research. Reading, MA: Addison-Wesley.

James, S. A. \& Stapp, W.B. 1974. Environmental Education, New York: John Willey \&Sons.

Luthans, Fred. 2002. The need for and meaning of essay positive organizational behavior. J. Organiz. Behav.

Luthans, F., \& Youssef, C. M. 2004. Human, social, and now positive psychological capital management: Investing in people for competitiveadvantage. Organizational Dynamics.

Luthans F, Avey JB, Avolio BJ, Combs G. 2006. Psychological Capital development : Toward a microintervention. Journal of Organizational Behavior, 27, 387-393.

Hurlock, E. B. 1990. Developmental Psychology: A Lifespan Approach. Boston: McGrawHill.

Madland, David. 2009. New Progressive America The Millenial Generation. Diakses dalam http://www.americanprogress.org/issues/2009/05/pdf/millennial_generation.pdf

Papalia, D E., Olds, S. W., \& Feldman, Ruth D. 2001. Human development (8th ed.). Boston: McGrawHill.

Soeryani Mohamad, dkk 2007. Lingkungan Hidup : Pendidikan, Pengelolaan Lingkungan, dan Kelangsungan Pembangunan. Edisi kedua. Jakarta. Yayasan Institut Pendidikan dan Pengembangan Lingkungan (IPPL).

Sudarmadji, 2008. Pembangunan Berkelanjutan, Lingkungan Hidup Dan Otonomi Daerah :Potret Lingkungan Hidup di Daerah. Dalam makalah Seminar Nasional Dies UGM ke-58 http://geo.ugm.ac.id/archives/125 [24-8-08].

-- The Millenial Generation. Diakses dalamhttp://www.indiana.edu/ $\sim$ oem/Retreat\%20Handouts/Millenial\%20Generation/Millennial\%20OEM\%20Retre at.pdf - Millenials : A Potrait Of Generation Net. Diakses dalamhttp://pewsocialtrends.org/ assets/pdf/millennials- confident-connected-opento-change.pdf 